UDC 678.023.5

M. Ye. Skyba ${ }^{1}$, Dr. Sc. (Tech.), Prof., orcid.org/0000-0003-0217-9633,

O. M. Synyuk ${ }^{1}$, Dr. Sc. (Tech.), Assoc. Prof., orcid.org/0000-0002-9615-0729,

B. M.Zlotenko ${ }^{2}$, Dr. Sc. (Tech.), Prof., orcid.org/0000-0002-0870-8535

\title{
MODEL OF CHANGING THE STRESSED-DEFORMED STATE OF A POLYMER SHEET DURING STRETCHING
}

Purpose. Development of methods for determining the degree of drawing, at which the transformation of the unoriented structure of the polymer sheet (geomembrane) into a highly oriented one begins, which increases its strength, and, thereafter, the durability in the process of gold extraction by heap leaching.

Methodology. The theoretical method for the investigation of the stress-strain state of a polymer sheet in the process of drawing on the basis of previously obtained experimental data.

Findings. The following has been developed: the model of the supramolecular spherulitic structure of amorphouscrystalline polymers in a non-oriented and oriented states; the method for determining the degree of drawing at which the destruction of the spherulitic structure of the polymer material begins.

Originality. For the first time, the problem of changing the stress-strain state of a polymeric material during its orientational drawing was solved by an analytical method. The developed mathematical model allows predicting the elastic properties of oriented amorphous-crystalline polymers of a spherulitic structure, which makes it possible to increase their strength in the desired direction.

Practical value. On the basis of theoretical studies, as well as the results of previously conducted experimental studies, a method was developed for determining the degree of drawing at which the destruction of the spherulitic structure of a polymeric material begins and a fibrillar structure is formed. This technique can be used while designing the equipment for the orientation of sheet polymer materials that are therefore used for strengthening polymer sheets (geomembranes), used for gold extraction by heap leaching.

Keywords: geomembrane, polymer, structure, orientational drawing, stress, strength

Introduction. Polymer sheets (geomembranes) are widely used in the construction of hydraulic systems: pools, sumps, dams, and others. Polymer sheets are especially important in the mining industry. For example, in the process of gold extraction, polymer plates can be placed under the base of the ore piles and at the bottom of the tank with processed solutions.

In the mining industry, the requirements of the physical-mechanical characteristics of polymer sheets are very high. The rupture of a geomembrane can lead to environmental pollution - penetration of cyanic solution into the ground and the groundwater, as well as loss of gold, which in the form of gold sand can leak through the rupture with the solution.

It is almost impossible to find and eliminate the rupture of the polymer sheet in the process of mining.

Nowadays there is a wide range of applications of polymer sheets. Geomembranes differ in the material from which they are produced (high, medium, and low density polyethylene), in thickness, size, and structure of the polymer [1].

One of the most important physical-mechanical characteristics of the polymer sheet is its tensile strength. It may vary depending on the polymeric material used for the geomembranes production. The tensile strength can reach $25 \mathrm{MPa}$ with low density polyethylene, and $35 \mathrm{MPa}-$ with high density polyethylene.

(C) Skyba M. Ye., Synyuk O. M., Zlotenko B. M., 2019
However, in the ore piles, the polymer sheet, in addition to the pressure of the soil and the solution, undergoes considerable pressure from the soil movement and subsidence. Therefore, obtaining high-strength geomembranes, which are used in the process of mining, is an urgent issue in the mining industry.

In this regard, the main task of this research is to simulate changes in the stress-strain state of a polymer sheet during stretching.

Analysis of the recent research and publications. High-strength polymer sheets can be obtained in two ways: at the stage of their production and by orientational deformation.

In the paper [2], the model of filling the mold with a polymeric material by injection molding is presented, which allows one to observe and influence the process of forming the structure of the product. The disadvantage of this method is that after filling the mold in order to avoid shrinkage, pressure exposure is required, during which the degree of orientation of the polymeric material structure is reduced [3].

In this paper we are investigating the second process for producing high-strength polymer sheets, i.e. their orientational deformation process $[4,5]$.

The main development direction of model ideas about the polymer structure is the modeling of changes in the polymer structure influenced by various strains [6]. This will allow quantitative description of the change in the physical-mechanical properties of polymers influenced by mechanical and temperature fields [7]. 
Many different supramolecular structural elements of a polymeric material, formed depending on the technology of polymer processing, do not allow us to describe their mechanical properties with a single model [8]. Hence, the main idea of this work is the model fixation of the main levels of the supramolecular structure of the polymer, which are formed at all stages of its deformation.

Undoubtedly, the most convenient object for studying the structural transformations occurring in polymers during their deformation is single crystals. However, the main and most common structural formation is a spherulitic structure [9], which is formed during the production of polyethylene geomembranes (Fig. 1).

Formulation of the problem. The structural model of a spherolitic polymer (Fig. 2) consists of two interrelated models describing two states of the supramolecular structure of polymers: before deformation - a model of an unoriented spherulite structure; after deformation - a model of an oriented spherulite structure of the polymer [10].

Taking the model shown in Fig. 1 as the original one, and taking into account the characteristics of structural elements [11] - spherulites and the amorphous phase, as well as their internal structure [12], neglecting dissipative phenomena in these elements, in the first approximate we

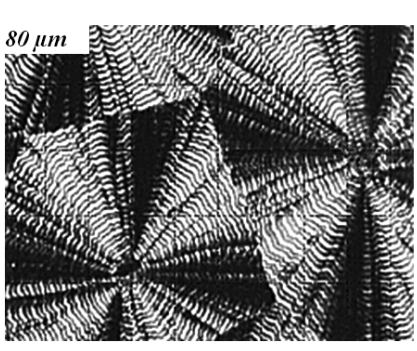

$a$

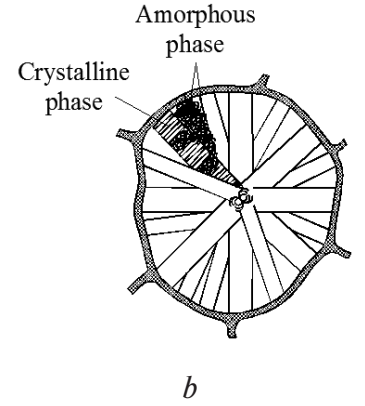

$b$
Fig. 1. Structural model of the spherolitic structure of a polymeric material:

$a$ - micrograph of spherulites; $b$-model of spherulite structure

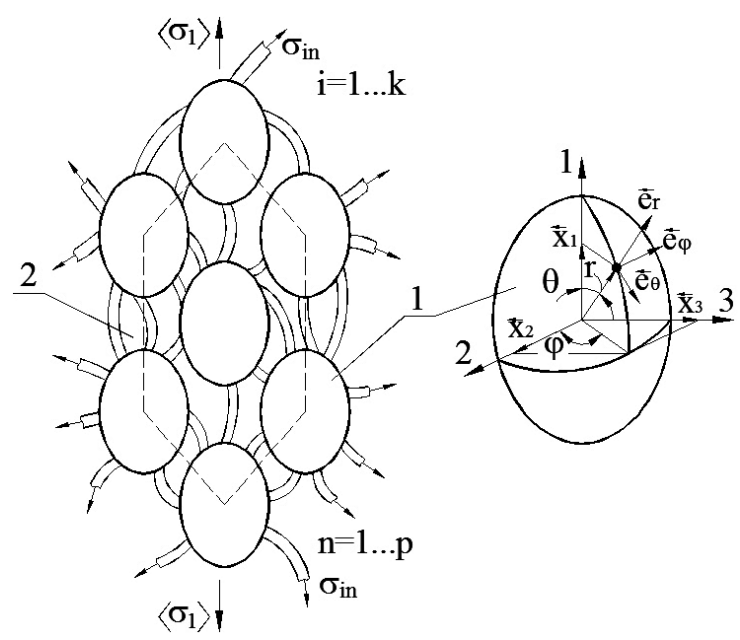

Fig. 2. Structural model of the polymeric material in the oriented state:

1 - spherulites (crystalline phase); 2 - amorphous phase divide the entire polymer drawing process into a finite number of its structural changes at a fixed degree of stretching. In the work [12], it was found that when the degree of stretching is equal to the natural one, the correlation between the original spherulite structure and the orientational one remains. At the same time, as the degree of drawing increases, the degree of flattening of spherulites increases, that is, spherulites change spherical shape, becoming elongated in the direction of orientation.

The above facts are the basis for the hypothesis of the existence of a quantitative correlation between the parameters of spherulites drawing and the elastic properties of the polymers in each of these states.

Consider a model of the unoriented state of the spherulitic structure [12], which undergoes uniaxial orientation with the degree of drawing $\lambda$. Fig. 2 shows a model for the transformation of the original non-oriented spherulitic structure into an oriented [2] in the direction of the axis $x_{1}$ and at a constant volume of spherulites [9] $\left(\rho_{c}=\right.$ const $)$.We will model the orientational drawing as a uniform compression (stretching) of the space [10]. In this case, uniform compression (stretching) of the spherulite actually occurs in the direction from the plane $x_{2} 0 x_{3}$, considered the main one (Fig. 3). Expressions for the coordinates transformation, taking into account the invariance of the spherulite volume, are as follows: $x_{1}^{*}=\lambda x_{1} \quad x_{2}^{*}=x_{3}^{*}=\lambda^{-1 / 2} x_{2}$. At $\lambda>1$ tensile strain of polymeric material takes place, and at $\lambda<1$ polymer compression strain occurs.

Spherulite equation with radius $r\left(x_{1}^{2}+x_{2}^{2}+x_{3}^{2}=r^{2}\right)$, uniformly stretched with drawing ratio $\lambda$, as a result of substitution of the coordinate transformation formulas and bringing it to the canonical form will be as follows

$$
\frac{\left(x_{1}^{*}\right)^{2}}{\lambda^{2} r^{2}}+\lambda \frac{\left(x_{2}^{*}\right)^{2}+\left(x_{3}^{*}\right)^{2}}{r^{2}}=1 \text {. }
$$

Expression (1) represents the equation of the rotated ellipsoid (spheroid). It should be borne in mind that if $\lambda>1$, then the spherulite has a shape elongated in the direction of the axis $x_{1}$ of rotated ellipsoid, and if $\lambda<1$, then it is compressed in the same direction. As a result of drawing, the spherical shape of spherulites is trans-

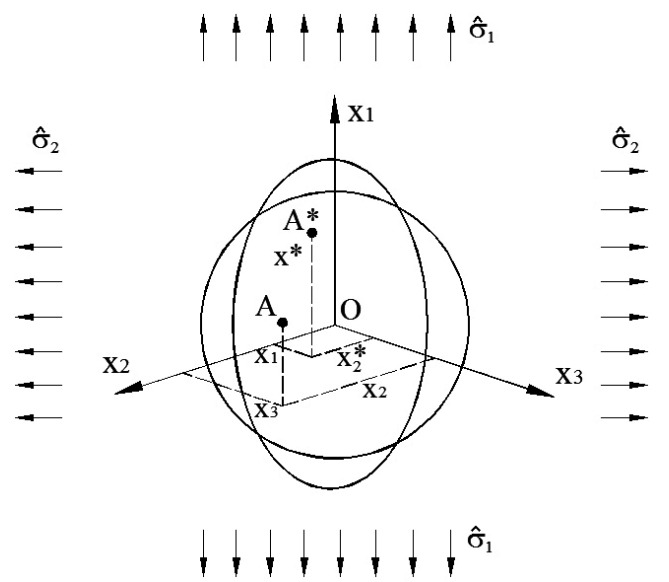

Fig. 3. The model of drawing of the polymer with a spherolitic structure 
formed into an ellipsoidal one. This fact is in satisfactory agreement with the results of numerous studies [7, 10].

The change in the shape of spherulites, as will be shown below, during the drawing process contributes to the emergence of a general anisotropy of the structure of the polymeric material with the isotropy of supramolecular formations (spherulites and amorphous phase).

The elastic constants of the deformed polymeric material will be determined based on the positions of the micromechanics of composite materials [13] with the involvement of both the Cartesian and curvilinear systems of degenerate ellipsoidal coordinates $v, \vartheta, \varphi$, the correlation between which is determined by the following expressions

$$
\begin{gathered}
x_{1}=r\left(\lambda^{2}-\lambda^{-1}\right)^{1 / 2} \operatorname{ch} u \cos \vartheta ; \\
x_{2}+i x_{3}=r\left(\lambda^{2}-\lambda^{-1}\right)^{1 / 2} \operatorname{sh} u \sin \vartheta e^{i \varphi} .
\end{gathered}
$$

Lamé coefficients of the system (2) are expressed by these equations

$$
\begin{gathered}
H_{u}^{2}=H_{\vartheta}^{2}=r^{2}\left(\lambda^{2}-\lambda^{-1}\right)\left(\operatorname{sh}^{2} u+\sin ^{2} \vartheta\right) ; \\
H_{\varphi}^{2}=r^{2}\left(\lambda^{2}-\lambda^{-1}\right) \cdot \operatorname{sh}^{2} u \cdot \sin ^{2} \vartheta .
\end{gathered}
$$

The first quadratic form of an element of arc length $d s$ is found in the following expression

$$
\begin{gathered}
d s^{2}=r^{2}\left(\lambda^{2}-\lambda^{-1}\right)\left[\left(\operatorname{sh}^{2} u+\sin ^{2} \vartheta\right)\left(d u^{2}+d \vartheta^{2}\right)+\right. \\
\left.+\operatorname{sh}^{2} u \sin ^{2} \vartheta d \varphi^{2}\right] .
\end{gathered}
$$

The unit vectors of the curvilinear $\mathbf{e}_{u}, \mathbf{e}_{\vartheta}, \mathbf{e}_{\varphi}$ and Cartesian $\mathbf{e}_{1}, \mathbf{e}_{2}, \mathbf{e}_{3}$ coordinate systems are connected by such ratios

$$
\begin{aligned}
& \mathbf{e}_{u}=a_{11} \cdot \mathbf{e}_{1}+a_{12} \cdot \mathbf{e}_{2}+a_{13} \cdot \mathbf{e}_{3} ; \\
& \mathbf{e}_{\vartheta}=a_{21} \cdot \mathbf{e}_{1}+a_{22} \cdot \mathbf{e}_{2}+a_{23} \cdot \mathbf{e}_{3} ; \\
& \mathbf{e}_{\varphi}=a_{31} \cdot \mathbf{e}_{1}+a_{32} \cdot \mathbf{e}_{2}+a_{33} \cdot \mathbf{e}_{3},
\end{aligned}
$$

where

$$
\begin{array}{ll}
a_{11}=\frac{\operatorname{sh} u \cos \vartheta}{\sqrt{\operatorname{sh}^{2} u+\sin ^{2} \vartheta}} ; & a_{21}=-\frac{\operatorname{ch} u \sin \vartheta}{\sqrt{\operatorname{sh}^{2} u+\sin ^{2} \vartheta}} ; \\
a_{12}=\frac{\operatorname{ch} u \sin \vartheta \cos \varphi}{\sqrt{\operatorname{sh}^{2} u+\sin ^{2} \vartheta}} ; & a_{22}=\frac{\operatorname{sh} u \cos \vartheta \cos \varphi}{\sqrt{\operatorname{sh}^{2} u+\sin ^{2} \vartheta}} ; \\
a_{13}=\frac{\operatorname{ch} u \sin \vartheta \sin \varphi}{\sqrt{\operatorname{sh}^{2} u+\sin ^{2} \vartheta}} ; & a_{23}=\frac{\operatorname{sh} u \cos \vartheta \sin \varphi}{\sqrt{\operatorname{sh}^{2} u+\sin ^{2} \vartheta}} ; \\
a_{31}=0 ; \quad a_{32}=-\sin \varphi ; & a_{33}=\cos \varphi .
\end{array}
$$

The inverse transformation is conducted using these equations

$$
\begin{aligned}
& \mathbf{e}_{1}=a_{11} \cdot \mathbf{e}_{u}+a_{21} \cdot \mathbf{e}_{\vartheta}+a_{31} \cdot \mathbf{e}_{\varphi} ; \\
& \mathbf{e}_{2}=a_{12} \cdot \mathbf{e}_{u}+a_{22} \cdot \mathbf{e}_{\vartheta}+a_{32} \cdot \mathbf{e}_{\varphi} ; \\
& \mathbf{e}_{3}=a_{13} \cdot \mathbf{e}_{u}+a_{23} \cdot \mathbf{e}_{\vartheta}+a_{33} \cdot \mathbf{e}_{\varphi} .
\end{aligned}
$$

Presentation of the main research. To determine the elastic constants, the stress state is represented as a system of stressed states - longitudinal and two-dimensional transverse tension, longitudinal tension, and longitudinal shear. A detailed consideration of the deformation of the spherulitic structure makes it possible to identify two types of deformation of the supramolecular structure during drawing: homogeneous and inhomoge- neous [10]. The uniform nature of the deformation of the spherulitic structure corresponds to spherulite, all parts of which stretch simultaneously and proportionally. Based on this, we conclude that when exposed to uniform stresses at infinity in an amorphous-crystalline medium, stresses in spherulite are homogeneous and of the same type, that is, normal and tangential stresses in spherulite at main sites do not mix with each other. The presence of both homogeneous and inhomogeneous deformation is characteristic of the interspherolite (amorphous) space, which indicates the dissipation of the mechanical energy of extrusion mainly in the interspherolite space. Thus, in the approximation of the linear theory, it can be assumed that between the elements of the supramolecular structure there are unknown stresses of the interaction between spherulites that act through an amorphous medium $\alpha_{1}^{\mathrm{o}}$.

To determine the stresses $\alpha_{1}^{0}$ we use the theorem of equivalent states $[9,15]$

$$
U=\frac{1}{2 V} \sum_{k=1} \int_{V_{k}} \sigma_{i k} \varepsilon_{i k} d V=\frac{1}{2 V} \int_{S_{*}} \sigma_{i n} u_{i} d S,
$$

where $U$ is potential energy of elastic deformation; $S_{*}$ is the given surface.

The first representation of the energy of elastic deformation through medium stresses $\hat{\sigma}_{i j}$ and deformations $\hat{\varepsilon}_{i j}$ in the case of longitudinal stretching is as follows

$$
U=\frac{1}{2} \hat{\sigma}_{1} \hat{\varepsilon}_{1}
$$

Expressing an elementary surface (4) as

$$
\begin{aligned}
d s=H_{\vartheta} d \vartheta H_{\varphi} d \varphi & =r^{2}\left(\lambda^{2}-\lambda^{-1}\right)\left(\operatorname{sh}^{2} u+\sin ^{2} \vartheta\right)^{0.5} \times \\
& \times \operatorname{sh} u \sin \vartheta d \vartheta d \varphi,
\end{aligned}
$$

and equating in the first approximation the reduced integration surface $S_{*}$ in (9) to the surface of an elongated spherulite, we obtain the expression for the potential energy

$$
\begin{gathered}
U=\frac{1}{2 V_{*}} \int_{S_{*}} \sigma_{i n} u_{i} r^{2}\left(\lambda^{2}-\lambda^{-1}\right) \times \\
\times\left(\operatorname{sh}^{2} u+\sin ^{2} \vartheta\right)^{0,5} \operatorname{sh} u \sin \vartheta d \vartheta d \varphi,
\end{gathered}
$$

where $V_{*}=\frac{4}{3} \pi r^{3}\left(\lambda^{2}-\lambda^{-1}\right)^{3 / 2} \operatorname{ch} u \operatorname{sh}^{2} u$ is the volume of the ellipsoid bounded by the reduced surface $S_{*}$

Considering that $\sigma_{i n} u_{i}=\sigma_{u}^{a} u_{u}^{a}+\sigma_{u \vartheta}^{a} u_{\vartheta}^{a}$, and using the first representation of the energy of elastic deformation, we obtain

$$
\begin{gathered}
\hat{\sigma}_{1} \hat{\varepsilon}_{1}=\frac{1}{V_{*}} \iint_{\left(S_{*}\right)}\left(\sigma_{u}^{a} u_{u}^{a}+\sigma_{u \vartheta}^{a} u_{\vartheta}^{a}\right) r^{2}\left(\lambda^{2}-\lambda^{-1}\right) \times \\
\times\left(\operatorname{sh}^{2} u+\sin ^{2} \vartheta\right)^{0,5} \operatorname{sh} u \sin \vartheta d \vartheta d \varphi .
\end{gathered}
$$

Substituting in equation (11) the values of uniform displacements $u_{u}^{\mathrm{o}}$ and $u_{\vartheta}^{\mathrm{o}}$, stress values $\sigma_{u}^{a}, \sigma_{u \vartheta}^{a}$ from [12], integrating (11) at $\varphi$ from 0 to $2 \pi$ and at $\vartheta$ from 0 to $\pi$ and using expressions for constants 


$$
\begin{aligned}
& A=\alpha_{1}^{0}\left(\frac{2\left[R 1_{s}-R 1_{a}\right]\left\{R 1_{s} \beta_{1}-\left[R 2_{a} \beta_{4}+E_{a}\left(1-3 v_{c}\right)\left(\beta_{3}+\beta_{4}\right)\right]\right\}-}{\left[R 1_{a} \gamma_{3}-R 1_{s} \gamma_{2}\right]\left\{R 1_{s} \beta_{1}-\left[R 2_{a} \beta_{4}+E_{a}\left(1-3 v_{s}\right)\left(\beta_{3}+\beta_{4}\right)\right]\right\}+}\right. \\
& \left.\frac{-\left[R 1_{s} \beta_{2}+R 1_{a} \beta_{3}\right]\left[R 2_{s}-E_{a}\left(1-v_{s}\right)\right]}{+\left[R 1_{s} \beta_{2}+R 1_{a} \beta_{3}\right]\left\{R 1_{s} \gamma_{1}-\left[R 2_{a} \gamma_{4}+E_{a}\left(1-3 v_{s}\right)\left(\gamma_{4}-\gamma_{3}\right)\right]\right\}}\right) ; \\
& F=\alpha_{1}^{0}\left(\frac{2\left[R 1_{s} \gamma_{2}-R 1_{a} \gamma_{3}\right]\left[R 2_{s}-R 2_{a}\right]-\left[R 1_{s}-R 1_{a}\right] \cdot\left\{R 1_{s} \gamma_{1}-\right.}{\left[R 1_{s} \beta_{2}+R 1_{a} \beta_{3}\right]\left\{R 1_{s} \gamma_{1}-\left[R 2_{a} \gamma_{4}+E_{a}\left(1-3 v_{s}\right)\left(\gamma_{4}-\gamma_{3}\right)\right]\right\}-}\right. \\
& \left.\frac{\left.-\left[R 2_{a} \gamma_{4}+E_{a}\left(1-3 v_{s}\right)\left(\gamma_{4}-\gamma_{3}\right)\right]\right\}}{-\left[R 1_{s} \gamma_{2}-R 1_{a} \gamma_{3}\right]\left[R 1_{s} \beta_{1}-\left[R 2_{a} \beta_{4}+E_{a}\left(1-3 v_{s}\right)\left(\beta_{3}+\beta_{4}\right)\right]\right\}}\right),
\end{aligned}
$$

where

$$
\begin{gathered}
R 1_{s}=E_{s}\left(1+v_{a}\right) ; \quad R 1_{a}=E_{a}\left(1+v_{s}\right) ; \\
R 2_{s}=E_{s}\left(1-v_{a}\right) ; \quad R 2_{a}=E_{a}\left(1-v_{s}\right) ; \\
\gamma_{1}=\frac{Q_{1}\left(\operatorname{ch} u_{0}\right)}{\operatorname{ch} u_{0}}-\frac{Q_{1}^{(1)}\left(\operatorname{ch} u_{0}\right)}{2 \operatorname{sh} u_{0}} ; \\
\gamma_{2}=\frac{Q_{1}\left(\operatorname{ch} u_{0}\right)}{\operatorname{ch} u_{0}}+\frac{Q_{1}^{(1)}\left(\operatorname{ch} u_{0}\right)}{2 \operatorname{sh} u_{0}} ; \\
\gamma_{3}=\frac{Q_{1}^{(1)}\left(\operatorname{ch} u_{0}\right)}{\operatorname{sh} u_{0}}-\frac{1}{2 \operatorname{ch} u_{0}} \frac{d Q_{1}^{(1)}\left(\operatorname{ch} u_{0}\right)}{d u_{0}} ; \\
\gamma_{4}=\frac{Q_{1}^{(1)}\left(\operatorname{ch} u_{0}\right)}{\operatorname{sh} u_{0}} ; \\
\beta_{1}=\left(3-4 v_{a}\right) \frac{Q_{1}\left(\operatorname{ch} u_{0}\right)}{\operatorname{ch} u_{0}}-\frac{Q_{1}^{(1)}\left(\operatorname{ch} u_{0}\right)}{\operatorname{sh} u_{0}}+\frac{\operatorname{ch} u_{0}}{2 \operatorname{sh} u_{0}} \frac{d Q_{2}\left(\operatorname{ch} u_{0}\right)}{d u_{0}} ; \\
\beta_{2}=\left(3-4 v_{a}\right) \frac{Q_{1}\left(\operatorname{ch} u_{0}\right)}{\operatorname{ch} u_{0}}-\frac{Q_{1}^{(1)}\left(\operatorname{ch} u_{0}\right)}{\operatorname{sh} u_{0}}+\frac{3 \operatorname{ch} u_{0}}{2 \operatorname{sh} u_{0}} \frac{d Q_{2}\left(\operatorname{ch} u_{0}\right)}{d u_{0}} ; \\
\beta_{3}=-\left(1-2 v_{a}\right)\left(\frac{Q_{1}\left(\operatorname{ch} u_{0}\right)}{\operatorname{ch} u_{0}}+\frac{Q_{1}^{(1)}\left(\operatorname{ch} u_{0}\right)}{\operatorname{sh} u_{0}}\right)+3 \frac{\operatorname{ch} u_{0}}{\operatorname{sh} u_{0}} \frac{d Q_{2}\left(\operatorname{ch} u_{0}\right)}{d u_{0}} ; \\
\beta_{4}=2\left(1-2 v_{a}\right)\left(\frac{Q_{1}\left(\operatorname{ch} u_{0}\right)}{\operatorname{ch} u_{0}}+\frac{Q_{1}^{(1)}\left(\operatorname{ch} u_{0}\right)}{\operatorname{sh} u_{0}}\right)+3 \frac{\operatorname{ch} u_{0}}{\operatorname{sh} u_{0}} \frac{d Q_{2}\left(\operatorname{ch} u_{0}\right)}{d u_{0}} ;
\end{gathered}
$$

we obtain the stress values of interaction between spherulites $\alpha_{1}^{0}$ depending on the current average stress $\hat{\sigma}_{1}$ and the drawing ratio $\lambda$

$$
\alpha_{1}^{0}=\frac{\hat{\sigma}_{1}}{1+\left(1-2 v_{a}\right) \chi^{2} A_{*}+\left(1+v_{a}\right) \chi^{2} F_{*}},
$$

where $\chi$ is the degree of crystallinity [14]; $A_{*}, F_{*}$ are constants with a structure corresponding to the expressions (12), and with functions $\gamma_{1}^{*} \ldots \gamma_{4}^{*}, \beta_{1}^{*} \ldots \beta_{4}^{*}$, determining the shape of spherulites, expressed through the degree of drawing $\lambda$

$$
\begin{gathered}
\gamma_{1}^{*}=\frac{\lambda \sqrt{\lambda} \ln a+\left(4-2 \lambda^{3}\right) \sqrt{\lambda^{3}-1}}{2\left(\lambda \sqrt{\lambda} \ln a+2 \lambda^{3} \sqrt{\lambda^{3}-1}\right)} ; \\
\gamma_{2}^{*}=\frac{3 \lambda \sqrt{\lambda} \ln a+\left(4+2 \lambda^{3}\right) \sqrt{\lambda^{3}-1}}{2\left(\lambda \sqrt{\lambda} \ln a+2 \lambda^{3} \sqrt{\lambda^{3}-1}\right)} ; \\
\gamma_{3}^{*}=\frac{\left(1-\lambda^{3}\right) \sqrt{\lambda^{3}-1}}{\lambda \sqrt{\lambda} \ln a+2 \lambda^{3} \sqrt{\lambda^{3}-1}} ; \\
\gamma_{4}^{*}=1 ;
\end{gathered}
$$

$$
\begin{gathered}
\beta_{1}^{*}=\left(1-2 v_{a}\right) \frac{\lambda \sqrt{\lambda} \ln a+2 \sqrt{\lambda^{3}-1}}{\lambda \sqrt{\lambda} \ln a+2 \lambda^{3} \sqrt{\lambda^{3}-1}}+ \\
+\frac{\left(2 \lambda^{3}+1\right) \ln a+6 \lambda \sqrt{\lambda^{4}-\lambda}}{4\left(\lambda^{3}-1\right)}+\gamma_{1}^{*} ; \\
\beta_{2}^{*}=2\left(1-2 v_{a}\right) \frac{\lambda \sqrt{\lambda} \ln a+2 \sqrt{\lambda^{3}-1}}{\lambda \sqrt{\lambda} \ln a+2 \lambda^{3} \sqrt{\lambda^{3}-1}}+ \\
+3 \frac{\left(2 \lambda^{3}+1\right) \ln a+6 \lambda \sqrt{\lambda^{4}-\lambda}}{4\left(\lambda^{3}-1\right)}+\gamma_{2}^{*} ; \\
\beta_{3}^{*}=-4\left(1-2 v_{a}\right)+3 \frac{\left(2 \lambda^{3}+1\right) \ln a+6 \lambda \sqrt{\lambda^{4}-\lambda}}{2\left(\lambda^{3}-1\right)} ; \\
\beta_{4}^{*}=2\left(1-2 v_{a}\right)- \\
-3 \frac{\left(2 \lambda^{3}+1\right) \ln a+6 \lambda \sqrt{\lambda^{4}-\lambda}+2\left(\lambda^{3}-1\right)}{2\left(\lambda^{3}-1\right)} ; \\
\ln a=\ln \frac{\lambda \sqrt{\lambda}-\sqrt{\lambda^{3}-1}}{\lambda \sqrt{\lambda}+\sqrt{\lambda^{3}-1}} .
\end{gathered}
$$

According to [11], we write the second energy representation in the following way

$$
\begin{aligned}
& \frac{\hat{\sigma}_{1}^{2}}{2 E_{1}}=\frac{r^{2}\left(\lambda^{2}-\lambda^{-1}\right)}{2 V_{*}} \iint_{\left.S_{*}\right)}\left(\sigma_{u}^{o} u_{u}^{a}+\sigma_{u \vartheta}^{o} u_{\vartheta}^{a}\right) \times \\
& \quad \times\left(\operatorname{sh}^{2} u+\sin ^{2} \vartheta\right)^{0,5} \operatorname{sh} u \sin \vartheta d \vartheta d \varphi .
\end{aligned}
$$

Substituting into (15) the values of uniform stresses $\sigma_{u}^{\mathrm{o}}$ and $\sigma_{u \vartheta}^{\mathrm{o}}$, displacement values $u_{u}^{\mathrm{a}}$ and $u_{\vartheta}^{\mathrm{a}}$ from [12] and solving the expression (9) relating to $E_{1}$, we determine the elastic modulus of the oriented polymeric material of the spherulitic structure in the direction $x_{1}$

$$
E_{1}=E_{a} \frac{1+\left(1-2 v_{a}\right) \chi^{2} A_{*}+\left(1+v_{a}\right) \chi^{2} F_{*}}{1-\left(1+v_{a}\right) \chi^{2} A_{* *}-\left(1+v_{a}\right) \chi^{2} F_{* *}},
$$

where $A_{* *}, F_{* *}$ are constants with a structure corresponding to the expressions (12), where functions $\gamma_{1}^{* *} \ldots \gamma_{4}^{* *}, \beta_{1}^{* *} \ldots \beta_{4}^{* *}$, determining the shape of spherulites, are expressed through the degree of drawing $\lambda$ in the following way

$$
\gamma_{1}^{* *}=\frac{\lambda \sqrt{\lambda} \ln a+\left(4-2 \lambda^{3}\right) \sqrt{\lambda^{3}-1}}{2\left(\lambda \sqrt{\lambda} \ln a+2 \sqrt{\lambda^{3}-1}\right)} ;
$$

ISSN 2071-2227, Naukovyi Visnyk NHU, 2019, № 1 


$$
\begin{gathered}
\gamma_{2}^{* *}=\frac{3 \lambda \sqrt{\lambda} \ln a+\left(4+2 \lambda^{3}\right) \sqrt{\lambda^{3}-1}}{2\left(\lambda \sqrt{\lambda} \ln a+2 \sqrt{\lambda^{3}-1}\right)} ; \\
\gamma_{3}^{* *}=\frac{\left(2-2 \lambda^{3}\right) \sqrt{\lambda^{3}-1}}{\lambda \sqrt{\lambda} \ln a+2 \sqrt{\lambda^{3}-1}} ; \\
\gamma_{4}^{* *}=\frac{\lambda \sqrt{\lambda} \ln a+2 \lambda^{3} \sqrt{\lambda^{3}-1}}{\lambda \sqrt{\lambda} \ln a+2 \sqrt{\lambda^{3}-1}} ; \\
\beta_{1}^{* *}=2-4 v_{a}+\frac{1}{2} \frac{\lambda \sqrt{\lambda}\left[\left(1+2 \lambda^{3}\right) \ln a+6 \lambda \sqrt{\lambda\left(\lambda^{3}-1\right)}\right]}{\left(\lambda \sqrt{\lambda} \ln a+2 \sqrt{\lambda^{3}-1}\right)\left(\lambda^{3}-1\right)}+\gamma_{1}^{* * *} ; \\
\beta_{2}^{* *}=2-4 v_{a}+\frac{3}{2} \frac{\lambda \sqrt{\lambda}\left[\left(1+2 \lambda^{3}\right) \ln a+6 \lambda \sqrt{\lambda\left(\lambda^{3}-1\right)}\right]}{\left(\lambda \sqrt{\lambda} \ln a+2 \sqrt{\lambda^{3}-1}\right)\left(\lambda^{3}-1\right)}+\gamma_{2}^{* *} ; \\
\beta_{3}^{* *}=4 v_{a}-2+3 \frac{\lambda \sqrt{\lambda}\left[\left(1+2 \lambda^{3}\right) \ln a+6 \lambda \sqrt{\lambda\left(\lambda^{3}-1\right)}\right]}{\left(\lambda \sqrt{\lambda} \ln a+2 \sqrt{\lambda^{3}-1}\right)\left(\lambda^{3}-1\right)} ; \\
\beta_{4}^{* *}=\left(2-4 v_{a}\right) \frac{\lambda \sqrt{\lambda} \ln a+2 \sqrt{\left(\lambda^{3}-1\right)}}{2\left(1-\lambda^{3}\right) \sqrt{\lambda^{3}-1}}- \\
-\frac{3}{2} \frac{\lambda \sqrt{\lambda}\left[\left(1+2 \lambda^{3}\right) \ln a+6 \lambda \sqrt{\lambda\left(\lambda^{3}-1\right)}\right]}{\left(\lambda \sqrt{\lambda} \ln a+2 \sqrt{\lambda^{3}-1}\right)\left(\lambda^{3}-1\right)} .
\end{gathered}
$$

Expression (16) allows determining the elastic modulus of oriented polymers of a spherolitic structure in the direction of deformation and requires, in the first one approximate knowledge of the elastic properties of the amorphous phase $E_{a}, v_{a}$, spherulites $E_{s}, v_{s}$, as well as structural and technological parameters of the recycling process, contributing to the change in the initial isotropic non-oriented structure and the formation of an oriented amorphous-crystalline medium.

Elastic constants of various polymers in amorphous state $E_{a}, v_{a}$ can be measured directly or taken from reference books [15]. As for the elastic constants of the crystalline phase $E_{s}, v_{s}$, then the use of the elastic modulus of the crystal lattice $E_{c r}$, as it was done in [16], in our opinion, is not correct. The complex structure of spherulites, which is, according to [4], the third after crystallites and lamellae level of supramolecular structure, in which both crystallites and lamellae, having a different orientation in space, are interconnected by intercrystalline amorphous layers, does not allow considering them as single crystalline morphoses. In $[4,10]$, it was established that spherulites, even at high final strains, deform with the polymer as a whole, stretching in the direction of drawing and only slightly lagging behind the deformation of the polymer.

As elastic constants of oriented spherulites $E_{s}, v_{s}$ it is proposed to use the values of elastic constants determined from equation (16) for the elastic modulus $E_{s}=E_{1}$ and [12] for the Poisson's ratio $v_{s}$ at the degree of crystallinity $\chi_{s}=\chi_{\max }$, being the maximum possible for a given polymer. In other words, the ideal structure of a spherulite is simulated, in which crystallites and (or) lamellae appear to be ellipsoidal inclusions in an amorphous matrix (Fig. 1a), which are ideally adhesively interconnected. The elastic modulus of such models of spherulites is equal to the elastic modulus of the crystal lattice $\left(E_{s}^{*}=E_{p}\right)$. The values of elastic constants obtained in this way can be used in further calculations as elastic spherulite constants $E_{s}, v_{s}$ for prediction of elastic properties, which are very important for determining the degree of drawing at which the transformation of the initial oriented spherulite structure of the polymer into oriented one begins.

Fig. 4 shows the dependences that allow one to determine the degree of drawing at which the destruction of the spherolitic structure of high density polyethylene (HDPE), medium density polyethylene (MDPE) and low density polyethylene ( $L D P E)$ begins.

Baseline data for curves 2, 4, 6 [15]:

HDPE $-E_{s}=8239 \mathrm{MPa}, v_{s}=0.32 ; E_{a}=2000 \mathrm{MPa}$, $v_{a}=0.39 ; \chi=0.40$.

MDPE $-E_{s}=5500 \mathrm{MPa}, v_{s}=0.35 ; E_{a}=3400 \mathrm{MPa}$, $v_{a}=0.39 ; \chi=0.10$.

LDPE $-E_{s}=1020 \mathrm{MPa}, v_{s}=0.37 ; E_{a}=77 \mathrm{MPa}, v_{a}=$ $=0.39 ; \chi=0.68$.

Curves 1, 3, 5 meet the experimental data obtained in $[15,16](\circ)$.Here are the results obtained from other sources [17] for $H D P E$ and $L D P E(\bullet)$.

Data analysis (Fig. 4) shows satisfactory coincidence of the predicted and measured values of the elastic modulus $E_{1}$, the maximum spread of values does not exceed $14 \%$ for HDPE, $16 \%$ for MDPE and $18 \%$ for $L D P E$.

It should be noted that when obtaining oriented polymeric materials as the technological value of the degree of drawing $\lambda$ the values corresponding to straight line dependencies are selected.

For these areas, the spread of values between the predicted and measured values is much smaller and is no more than $8 \%$ for $H D P E$, no more than $10 \%$ for $L D P E$, and almost complete coincidence for MDPE. The increase in the spread between the predicted and experimental values for high degrees of drawing is explained,

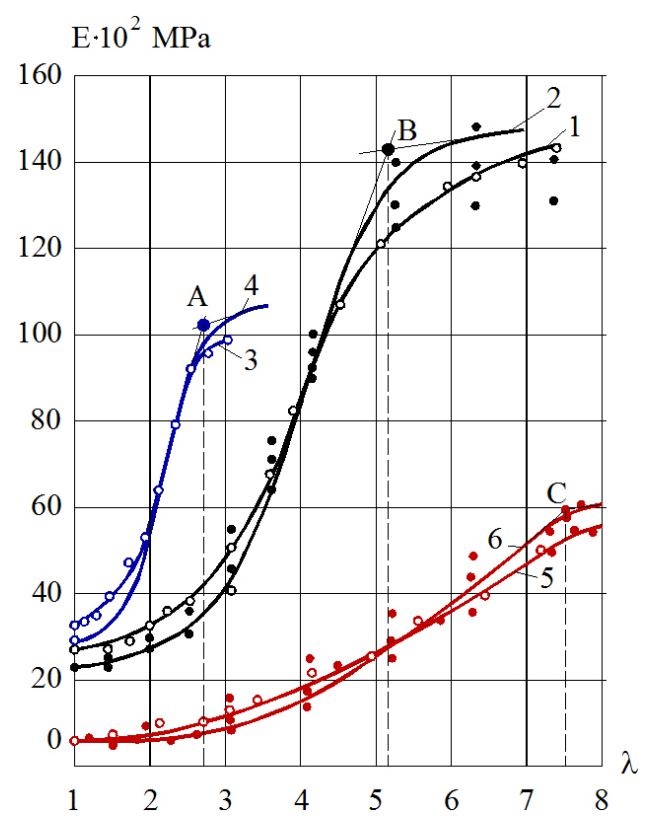

Fig. 4. Dependencies of elastic modulus $\operatorname{HDPE}(1,2)$, MDPE $(3,4)$ and LDPE $(5,6)$ on the degree of drawing 
apparently, by the beginning of the destruction of the original oriented spherulitic structure and its transformation into a fibrillar one.

Conclusions and recommendations. The dependencies shown in Fig. 4, allow determining the degree of drawing, corresponding to the natural one, at which the destruction of the spherulitic structure begins. The example of curve 2 (point B) shows the method for determining the degree of natural polymer stretching $\lambda_{p}$ that can serve as a guideline in the design of equipment intended for the hardening of polymer sheets.

Considering the passage to the limit in the equation (16) at $\lambda=1$, it can be shown that equation (16) takes the form corresponding to the model of the unoriented structure of the polymeric material and satisfactorily describes the experimental data.

Further studies are planned on the dependence of the elastic modulus of polymer sheets on shear stresses, as well as on the totality of tensile and shear stresses.

In conclusion, the authors express their gratitude to V. V. Kostritsky for the constant attention and valuable comments made in the course of this work.

\section{References.}

1. Teleshev, V. I. and Lupachev, O. Yu., 2009. Anti-filtration elements from geomembranes. Experience in hydrotechnical construction. Inzhenerno-stroitelnyiy zhurnal [pdf], 6, pp. 35-43. Available at: <http://engstroy.spbstu.ru/index_2009_06/lupachev_geomembrany.pdf> [Accessed 14 October 2017].

2. Kulik, T., Synyuk, O. and Zlotenko, B., 2017. Modeling a process of filling the mold during injection molding of polymeric parts. Eastern-European Journal of Enterprise Technologies, 5/1(89), pp. 70-77.

3. Akay, M., 2012. Introduction to Polymer Science and Technology. New York: Publishing ApS [pdf]. Available at: $<$ http://www.iqytechnicalcollege.com/ME\%20209\%20 Introduction-to-polymer-science-and-technology.pdf> [Accessed 3 December 2017].

4. Argon, A. S., 2013. The Physics of Deformation and Fracture of Polymers. New York: Cambridge University Press. 5. Isayev, A.I., ed., 2016. Encyclopedia of Polymer Blends. Vol. 3: Structure. New York: John Wiley \& Sons. 6. Koseki, Yu., Keitaro, A. and Shinji, A., 2012. Crystalline structure and molecular mobility of PVDF chains in PVDF/PMMA blend films analyzed by solid-state $\mathrm{F}$ MAS NMR spectroscopy. Polymer Journal [pdf], 44, pp. 757-763. Available at: <https://pdfs.semanticscholar.org/02ed/9ea59ee2d193802562b86341e5a55d4d57 9c.pdf> [Accessed 22 November 2017].

7. Stoclet, G., Seguela, R., Vanmansart, C., Rochas, C. and Lefebvre, J.-M., 2012. WAXS study of the structural reorganization of semi-crystalline polylactide under tensile drawing. Polymer Journal [online], 53(2), pp. 519-528. Available at: <https://www.sciencedirect. com/science/article/pii/S0032386111010019> [Accessed 22 November 2017].

8. Kireev, V. V., 2013. High-molecular compounds. Moscow: Yurayt.

9. James, E., Kenneth, S., Watkins, B., Watkins, J., Hesse, M. and Miller, N., 2012. Compositional gradi- ents surrounding spherulites in obsidian and their relationship to spherulite growth and lava cooling. Springer [pdf], 4, pp. 229-243. Available at: <https://pages.uoregon.edu/watkins4/pubs/2012_Gardner_etal.pdf $>$ [Accessed 7 January 2018].

10. Ohlopkova, T.A., Borisov, R. V., Ohlopkova, A.A., Dyakonov, A.A., Vasilev, A.P. and Mironova, S. N., 2015. Microscopic studies of deformation of stretching of spherulitic structures in polymeric composite materials. Vestnik of the North-Eastern Federal University named after M. K. Ammosov, 3(47), pp. 75-87.

11. Synyuk, O. M., 2016. Model structure undeformed polymer spherulitic structure. Bulletin of Khmelnytsky National University. Series "Technical sciences", 3(237), pp. $181-188$.

12. Synyuk, O. M., 2016. Determination of the elastic properties of amorphous-crystalline polymer of spherulites structure. Bulletin of Vinnytsia National Technical University. Series "Technical sciences", 6, pp. 77-86.

13. Abdikarimov, M. N. and Turgumbaeva, R.H., 2015. Physical-mechanical properties of polymer composite materials, including waste products. Modern high technologies, 5, pp. 7-11.

14. Wen, T., Zhou, Y., Liu, G., Wang, F., Zhang, X., Wang, D., Chen, H., Walton, K., Marchand, G. and Loos, J., 2012. Epitaxial crystallization of olefin block copolymers (OBCs) on uniaxially oriented isotactic polypropylene and high-density polyethylene films. Polymer Journal [online], 53(2), pp. 529-535. Available at: <https://www.sciencedirect.com/science/article/pii/ S0032386111010007> [Accessed 19 January 2018].

15. Utracki, L.A. and Wilkie, C.A., 2014. Polymer Blends Handbook. Netherlands: Springer.

16. Brazel, Christopher S. and Rosen, Stephen L., 2012. Fundamental principles of polymeric materials. New Jersey: John Wiley \& Sons [pdf]. Available at: $<$ https://theeye.eu/public/Books/Materials\%20science\% 20 and $\% 20$ engineering/M213\%20 Polymers/Christopher\%20S.\%20Braze1\%2C\%20Stephen\%20L.\%20 Rosen-Fundamenta1\%20Principles $\% 20$ of\% 20Polymeric\%20Materials-Wiley\%20\%282012\%29.pdf> [Accessed 3 November 2017].

17. Fakirov, S., 2017. Fundamentals of Polymer Science for Engineers. Weinheim: Wiley-VCH Verlag GmbH \& Co. KGaA.

\section{Модель зміни напружено-деформованого стану листа полімеру під час його розтягу}

\author{
М. С. Скиба ${ }^{1}$, О. М. Синюк ${ }^{1}$, Б. М. Злотенко ${ }^{2}$
}

1 - Хмельницький національний університет, м. Хмельницький, Україна, e-mail: synoleg@ukr.net

2 - Київський національний університет технологій та дизайну, м. Київ, Україна, e-mail: zlotenco@ukr.net

Мета. Розробка методики визначення ступеня витяжки, за якої починається перетворення неорієнтованої структури полімерного листа (геомембрана) у високоорієнтовану, що дозволить збільшити його міцність, а, відповідно, і довговічність у процесі видобутку золота купчастим вилуговуванням. 
Методика. Теоретичний метод дослідження напружено-деформованого стану полімерного листа у процесі його витяжки на основі експериментальних даних, отриманих раніше.

Результати. Розроблені: модель надмолекулярної сферолітної структури аморфно-кристалічних полімерів у неорієнтованому та орієнтованому стані; методика визначення ступеня витяжки, за якої починається руйнування сферолітної структури полімерного матеріалу.

Наукова новизна. Уперше аналітичним методом вирішена задача щодо зміни напружено-деформаційного стану полімерного матеріалу у процесі його орієнтаційної витяжки. Розроблена математична модель дозволяє прогнозувати пружні властивості орієнтованих аморфно-кристалічних полімерів сферолітної будови, що дає можливість підвищувати їх міцність у необхідному напрямку.

Практична значимість. На підставі результатів теоретичних досліджень, а також результатів проведених раніше експериментальних досліджень, розроблена методика визначення ступеня витяжки, за якої починається руйнування сферолітної структури полімерного матеріалу та утворюється фібрилярна структура. Дана методика може бути використана при проектуванні обладнання для орієнтування листових полімерних матеріалів, що дозволить зміцнювати полімерні листи (геомембрани), які використовують при видобутку золота купчастим вилуговуванням.

Ключові слова: геомембрана, полімер, структура, орієнтаційна витяжкка, напруга, міцність

\section{Модель изменения напряженно- деформированного состояния листа полимера при его растяжении}

\section{Н. Е. Скиба ${ }^{1}$, О.Н. Сынюк ${ }^{1}$, Б.Н. Злотенко}

1 - Хмельницкий национальный университет, г. Хмельницкий, Украина, e-mail: synoleg@ukr.net

2 - Киевский национальный университет технологий и дизайна, г. Киев, Украина, e-mail: zlotenco@ukr.net
Цель. Разработка методики определения степени вытяжки, при которой начинается преобразование неориентированной структуры полимерного листа (геомембрана) в высокоориентированную, что позволит увеличить его прочность, а, соответственно, и долговечность в процессе добычи золота кучным выщелачиванием.

Методика. Теоретический метод исследования напряженно-деформированного состояния полимерного листа в процессе его вытяжки на основе экспериментальных данных, полученных ранее.

Результаты. Разработаны: модель надмолекулярной сферолитной структуры аморфно-кристаллических полимеров в неориентированном и ориентированном состоянии; методика определения степени вытяжки, при которой начинается разрушение сферолитной структуры полимерного материала.

Научная новизна. Впервые аналитическим методом решена задача об изменении напряженно-деформационного состояния полимерного материала в процессе его ориентационной вытяжки. Разработанная математическая модель позволяет прогнозировать упругие свойства ориентированных аморфно-кристаллических полимеров сферолитного строения, что дает возможность повышать их прочность в необходимом направлении.

Практическая значимость. На основании результатов теоретических исследований, а также результатов проведенных ранее экспериментальных исследований, разработана методика определения степени вытяжки, при которой начинается разрушение сферолитной структуры полимерного материала и образовывается фибриллярная структура. Данная методика может быть использования при проектировании оборудования для ориентирования листовых полимерных материалов, что позволит упрочнять полимерные листы (геомембраны), которые используют при добыче золота кучным выщелачиванием.

Ключевые слова: геомембрана, полимер, структура, ориентационная вытяжка, напряжение, прочность

Рекомендовано до публікації докт. техн. наук О. В. Дихою. Дата надходження рукопису 18.07.17. 